 I K O Ś C I E L N N E
}

KOŚCIÓŁ I PRAWO 10(23) 2021, nr 2, s. 9-30

DOI: https://doi.org/10.18290/kip21102.1

\author{
Oleksandr Bilash \\ Tetyana Karabin \\ Mykhailo Savchyn
}

\author{
PRESERVATION AND PROTECTION \\ OF THE CULTURAL HERITAGE \\ OF RELIGIOUS PURPOSES IN UKRAINE
}

\section{INTRODUCTION}

Since the 1990s, 3.6 thousand churches and more than 10,000 objects of religious and ecclesiastical use, which belonged to religious organizations before "nationalization" and were used in the Soviet period for other purposes, have been returned to them in Ukraine based on appeals from religious communities "for the return of religious buildings and other property" [Kot 2018, 30]. Such processes became possible due to purposeful

DR. OlEKSANDR BILASH - Department of Administrative, Financial and Information Law, Uzhhorod National University; correspondence address: Kapitulna street 26, 88000 Uzhhorod, Ukraine; e-mail: oleksandr.bilash@uzhnu.edu.ua; https:/orcid.org /0000-0002-1248-7798

PROF. DR. HABIL. TETYANA KARABIN - Department of Administrative, Financial and Information Law, Uzhhorod National University; correspondence address: Kapitulna street 26, 88000 Uzhhorod, Ukraine; e-mail: tetyana.karabin@uzhnu.edu.ua; https:// orcid.org/0000-0002-6538-5269

Prof. DR. HABIL. MYKhaIlo SAVChyN - Department of Administrative, Financial and Information Law, Uzhhorod National University; correspondence address: Kapitulna street 26, 88000 Uzhhorod, Ukraine; e-mail: michaelsavchyn7@gmail.com; https:// orcid.org/0000-0002-9551-1203 
state policy and the following adopted regulatory acts: Presidential Order "On Measures to Return of Cultural Property to Religious Organizations" No. 1257 of March 4, 1992, Presidential Decree "Return of Cult Property to Religious Organizations" No. 53 of June 22, 1996, Decree of the Cabinet of Ministers of Ukraine "Regarding the Providing Gradual Return to Religious Organizations the Religious Buildings that are Not Used or are Used for Other Purposes" No. 290-r of May 7, 1998, Resolution of the Cabinet of Ministers of Ukraine "On the Conditions of Transfer of Religious Premises-Famous Architectural Landmarks to Religious Organizations" No. 137 of February 14, 2002.

Undoubtedly, positively assessing the acts of return of religious buildings and property to religious communities, one cannot avoid the issue of protection and preservation of such buildings within the general problem of protection of cultural heritage in Ukraine. In many cases, the transfer of religious buildings and valuables has led to conflicts between the interests of a particular religious community and the state's interest in the protection and preservation of relevant cultural heritage objects. Often, heritage objects owned or used by religious organizations are perceived by the latter not as valuables, the historical heritage of the whole nation, but purely functionally [Tokman 2014]. There are quite a few cases of unauthorized rearrangement and reconstruction of ancient temples, changes in their decoration, as well as violations of the modes of their maintenance [Bondarenko, Putova and Koval'ov 2008]. The obvious result of such problems existence was the mass destruction of cult architectural landmarks transferred to religious communities as a result of fires,${ }^{1}$ including arson [Boyko 2008]. In total, 164 churches burned down in Ukraine only in the period 2000-2006. Among them in 2000 - 21 churches, in $2001-23$, in $2002-28$, in $2003-22$, in $2004-22$, in $2005-19$, in $2006-29$. After 2000 the situation has not significantly improved. ${ }^{2}$ In total, about 200 ancient temples have burned down and been disassembled in Ukraine since 1991 [Kot 2015, 80-81].

This state of affairs is a consequence not only of inappropriate management decisions and erroneous organizational actions. Preservation of religious cultural heritage should find proper doctrinal study and legal

\footnotetext{
${ }^{1}$ Sad statistics of burned churches, https://zommersteinhof.dreamwidth.org/130138. html [accessed: 05.10.2021].

${ }^{2}$ Destroyed churches, http://decerkva.org.ua/burned.html [accessed: 05.10.2021].
} 
regulation in legislative acts. Accordingly, this article deals with the attempts to formulate legal problems and propose their solutions in the field of protection of cultural heritage, which is used for religious purposes.

\section{TERMINOLOGICAL ISSUES}

There is no unanimously agreed definition of cultural heritage - either at law or in the wider practical and theoretical literature on the topic around the globe [Connolly 2015, 18]. This term includes cultural objects, cultural property and cultural patrimony. Ukraine also does not fully formulate a view on the use and protection of cultural heritage as a holistic phenomenon, which is the object of comprehensive administrative and legal regulation. Among the reasons for this state of affairs are inconsistencies in the terminological plan and incomplete regulation. In the field of legal regulation of cultural heritage, the legislation uses such concepts as the object of cultural heritage, cultural heritage landmarks, historical and cultural landmarks, cultural values, cultural goods, attainment and others. Their protection is regulated by various regulations, different institutional instruments of protection are formed.

The term cultural values is used to denote movable objects of material and spiritual culture (paintings, graphics and sculptures, manuscripts, ancient books, museum objects, etc.) that have artistic, historical, ethnographic and scientific significance. To register them, the State Register of National Cultural Property is formed, the maintenance of which is provided by the laws "On Culture" (Part 3 of Article 16), "On Museums and Museum Affairs" (Part 1 of Article 16), "On Libraries and Library Affairs" (Part 3 of Article 16), "On the National Archival Fund and Archival Institutions" (Part 1 of Article 14) and regulated by the Resolution of the Cabinet of Ministers of Ukraine No. 466 of August 12, 1992. Among the classification types of the register there are the following: written, visual and material. ${ }^{3}$

Another type of cultural heritage that is subject to regulatory protection is intangible cultural heritage. It includes customs, forms of presenting

\footnotetext{
${ }^{3}$ Data from the site, https://data.gov.ua/dataset/014aba3a-63ed-4edf-b6b1-b26f1ad 29953 [accessed: 25.09.2021].
} 
and expression, knowledge, skills passed down from generation to generation, constantly reproduced by communities and groups under the influence of their experience, environment, interaction with nature, history and form in them a sense of identity and continuity, thus contributing respect for cultural diversity and human creativity (Law "On Culture"). It is defined and protected by the UNESCO Convention for the Safeguarding of the Intangible Cultural Heritage of 2003, the Law on Culture (Articles 2, 16), and the list of its elements is maintained under the Order of the Ministry of Culture of Ukraine of February 12, 2018 No. 105 "On Approving the National List of Elements of Intangible Cultural Heritage of Ukraine."

However, in our opinion, it is expedient to include immovable objects in the common group of objects of material and spiritual culture. Immovable cultural heritage is subject to the protection of the law "On Protection of Cultural Heritage," if determined by the object of cultural heritage, ${ }^{4}$ or "On Protection of Archaeological Heritage," if determined by the object of archaeological heritage. ${ }^{5}$

Such an interpretation is often criticized by the scientific community [Yepifanov 2018, 30-32; Mazur 2021, 58-66]. It is also not fully in line with the broad interpretation of the term by the Council of Europe Framework Convention on the Importance of Cultural Heritage for Society of 2005, which defines cultural heritage as a collection of resources inherited from the past that people, regardless of their affiliation, consider the reflection and expression of their ever-changing values, beliefs, knowledge and traditions; it covers all aspects of the environment that have arisen as a result of the interaction in time between people and places. However, the study of immovable cultural heritage in the joint group complies with the

${ }^{4}$ An object of cultural heritage is a landmark, structure (work), complex (ensemble), their parts, related movable objects, as well as territories or water objects (objects of underwater cultural and archaeological heritage), other natural, natural-anthropogenic or human-made objects, regardless of the state of preservation, which have brought to our time value from the archaeological, aesthetic, ethnological, historical, architectural, artistic, scientific or artistic point of view and have retained their authenticity.

${ }^{5}$ The object of archaeological heritage is a place, structure (work), complex (ensemble), their parts, related territories or water objects created by human, regardless of the state of preservation, which have brought to our time values from the archaeological, anthropological and ethnographic point of view and fully or partially preserved their authenticity. 
provisions of the UNESCO Convention Concerning the Protection of the World Cultural and Natural Heritage of 1972, which regulates that cultural heritage means the following: landmarks: works of architecture, monumental sculpture and painting, archaeological elements and structures, inscriptions, caves and groups of elements that have outstanding universal value in terms of history, art or science; ensembles: groups of isolated or combined buildings, the architecture, unity or connection with the landscape of which is an outstanding universal value in terms of history, art or science; sights: works of a human or joint creations of human and nature, as well as areas, including archaeological sites, which are of universal value in terms of history, aesthetics, ethnology or anthropology.

In addition, recording the cultural and archaeological landmarks in Ukraine is kept in the unified State Register of Immovable Monuments of Ukraine ${ }^{6}$ which is actively formed by the Ministry of Culture and Information Policy of Ukraine by categories of national and local landmarks. It is this group of objects of immovable material and spiritual culture that is currently the subject of regulation of the institution of cultural heritage law. And in the context of this group of immovable objects, this article will reveal the issues of cultural heritage used for religious purposes.

\section{CONSTITUTIONAL AND INTERNATIONAL LAW FRAMEWORKS OF LEGAL REGULATION}

The objectification of the protection of religious and cultural heritage in the form of cultural rights of man and citizen should be reflected at the constitutional and legal level with further development and detailing at the level of special branches of the national legal system [Yepifanov 2017, 34]. Therefore, the objects of such heritage are inseparably considered in the context of the institution of protection of cultural heritage and ensuring the cultural rights of man and citizen, and the principles of the legal regime of protection are reflected in the provisions of the Constitution of Ukraine. Thus, Article 54 of the Constitution of Ukraine establishes that cultural heritage is protected by law; the state ensures the preservation of

\footnotetext{
${ }^{6}$ Data from the site: https://mkip.gov.ua/content/derzhavniy-reestr-neruhomih-pa myatok-ukraini.html [accessed: 25.09.2021].
} 
historical landmarks and other objects of cultural value, takes measures to return to Ukraine the cultural values of the people who are outside it. Article 66 also stipulates the obligation of everyone not to harm nature, cultural heritage, to compensate for the damage caused by him.

At the same time, the constitutional provisions are aimed not only at protecting and preventing harmful effects on heritage, but also at its rational use at both national and local levels, creating legal guarantees for free access to such values, establishing the appropriate scope of public bodies competences, as well as the competences of local self-governments.

However, at the national level, there may be a lack of resources required for the protection of cultural heritage used for religious purposes, as well as the economic, scientific and technical resources of a state in which the protected object is located. Therefore, acts of international law are also important for protection.

The Association Agreement between Ukraine, of the one part, and the European Union, the European Atomic Energy Community and their Member States, of the other part, also provides that the Parties shall cooperate closely in relevant international forums and organizations, including the United Nations Educational, Scientific and Cultural Organization (UNESCO) and the Council of Europe (CoE), with a view, inter alia, to the development of cultural diversity, the preservation and appreciation of cultural and historical heritage (Article 439). The action plan for the implementation of the provisions of the Agreement until December 31, 2021 plans to develop and approve the Concept of implementation of electronic accounting and presentation of cultural heritage objects and cultural values; development and adoption of the order of the Ministry on amendments to the Procedure for registration of cultural heritage objects; development of IT-infrastructure for the introduction of electronic information resource of cultural heritage and cultural values; implementation of a pilot project for the introduction of electronic accounting of cultural heritage objects; commissioning of an electronic information resource of cultural heritage and cultural values.

However, unfortunately, the Ministry of Culture and Information Policy of Ukraine, contrary to the requirements of Ukrainian legislation, the Medium-Term Action Plan of the Government until 2020, the Action Plan to implement the Association Agreement has not been developed and submitted to the Cabinet of Ministers of Ukraine creation of an electronic 
information resource of cultural heritage and cultural values; no orders have been issued to approve the regulations on the electronic information resource of cultural heritage and cultural values and the procedure for its maintenance; the technical task for the test version of the software and implementation of the pilot project of generation and exchange of electronic unified data on objects of cultural heritage and cultural values has not been developed. ${ }^{7}$

The UNESCO Convention Concerning the Protection of the World Cultural and Natural Heritage of November 16, 1972, ratified by the Decree of the Presidium of the Verkhovna Rada of the Ukrainian SSR No. 6673$\mathrm{XI}$ of October 4, 1988, is one of the fundamental international acts concerning the protection of religious heritage. The international protection of the World Cultural and Natural Heritage in the Convention means the establishment of a system of international cooperation and assistance to the States Parties in their efforts to preserve and identify this heritage. However, the Convention undertakes to ensure the identification, protection, preservation, promotion and transmission to future generations of the cultural and natural heritage of the State in whose territory the heritage is located. To this end, the State must act both on its efforts, making the best use of available resources and, if necessary, using international assistance and cooperation, which it may enjoy, in particular in financial, artistic, scientific and technical terms.

Among the international acts of the Council of Europe in the field of protection of religious and cultural heritage is the European Cultural Convention of December 19, 1954, ratified by the Verkhovna Rada of Ukraine No. 4030-XII on February 24, 1994 and the Convention on the Protection of European Architectural Heritage of October 3, 1985, ratified on September 20, 2006 No. 165-V and the European Convention on the Protection of the Archaeological Heritage (revised) of January 16, 1992, ratified on December 10, 2003 No. 1369-IV.

\footnotetext{
${ }^{7}$ Audit of the effectiveness of the use of state budget funds allocated for general management and administration in the field of culture: Decision of the Accounting Chamber No. 3-2 of February 25, 2020.
} 


\section{SPECIFIC ACCESSION OF RELIGIOUS CULTURAL HERITAGE OBJECTS}

\subsection{Legislative classification}

At the national level, the basic law governing legal, organizational and economic relations in the field of protection of religious heritage is the Law "On Protection of Cultural Heritage." It contains provisions on the classification of cultural heritage objects by types and species, but none of these classifications allocates objects with religious purposes to a separate group. ${ }^{8}$ According to the types of objects, the law divides them into buildings, complexes and landmarks. By types of cultural heritage objects are divided into archaeological, historical, monumental art objects, architectural objects, urban planning objects, objects of garden and park art, landscape objects, objects of science and technology (Article 2 of the law).

However, it is certainly impossible to determine effective means of preserving cultural heritage objects without the development of appropriate classification systems, which reflect the fundamental specifics of the studied objects. Real estate contains a wide range of meaningful information. The scientific classification specific to this type of objects is based on this principle that is not reflected in the law. Thus, according to the content of concentrated information, they are separated into objects (sights) 1) the state system and socio-economic system; 2) socio-political life, social and national liberation movements; 3) military history; 4) production and equipment; 5) science, education, culture; 6) religious and church life [Fedorova 2015, 198].

Of course, according to the formal and typological features of the carriers of this information in the context of our article, we are talking about two types of objects defined by law: buildings (buildings) and complexes (ensembles). Moreover, the normative definition of buildings includes not

\footnotetext{
${ }^{8}$ Under religious buildings we consider buildings of religious purposes specifically designed to meet the religious needs of citizens. Therefore, in particular, those premises that are adapted for the residence of priests and others cannot be recognized as such, if they are not an integral part of the cult building and are not located on the land plot necessary for the maintenance of this building (gatehouse, etc.). On some issues that arise in the application of the Law of Ukraine "On Freedom of Conscience and Religious Organizations": Clarification of the Supreme Arbitration Court No. 025/109 of February 29, 1996.
} 
only works of architecture and engineering, but also works of monumental sculpture and monumental painting. Therefore, wall icons, as well as various plastic images included in the interior or exterior of religious buildings, are also an integral part of the object. By the way, on the territory of modern Ukraine monumental painting in the form of frescoes, mosaics, murals, panels, stained glass, etc. has always been one with architectural structures [Kovpanenko 1999, 212-45]. Therefore, a significant part of the visual heritage of Ukraine (about 70 percent) is preserved in architectural monuments, and only 30 percent -in museums [Slipchenko $2001,132]$. And as a specific kind of monumental art we consider the iconostasis, which occupied one of the most important places in the interior decoration of Orthodox sacred buildings. It is a combination of architecture, icon painting and decorative carving.

Complexes (ensembles) as objects of cultural and religious heritage are topographically defined sets of separate or combined objects. For example, the ensemble of the Church of the Assumption in Lviv, consisting of the Kornyakt Tower, the Chapel of the Three Saints and the Church of the Assumption itself. The same ensembles are monastic complexes, in particular in the village of Mezhyrichchya, Rivne region, such a complex is formed by the Trinity Church and cells, the gate bell tower and the southeastern building.

\subsection{Landmarks}

In the case of religious cultural heritage, the identification and delimitation process should be based on the official instruments relating to the active choice as to which elements of this cultural "galaxy" are deemed worthy of preservation as an "inheritance" for future generations [Tsivolas $2014,49]$. That is why the allocation of landmarks among all objects of religious and cultural heritage becomes important.

In scientific research, scientists have for some time sought meaningful differences between "landmarks" and "monuments," but concluded that monuments are sculptural and architectural structures erected to glorify a particular historical event, in honor of a historical figure, and landmark, as a term, has a much broader meaning, is used to denote an object or a set of objects of material and spiritual culture of the past that have scientific, historical, artistic and other cultural significance [Kot 2009]. 
This approach is also reflected in regulations. According to the legislative definition, a cultural heritage landmark is an object of cultural heritage, which is entered in the State Register of Immovable Monuments of Ukraine, or an object of cultural heritage, which is registered in accordance with the legislation in force before the Law "On Protection of Cultural Heritage" came into force, until resolving the issue of inclusion (noninclusion) of cultural heritage objects in the State Register of Immovable Monuments of Ukraine (Article 1 of the Law "On Protection of Cultural Heritage").

On the territory of Ukraine there are about 180000 cultural heritage objects that are on the state register, of which - 15843 monuments entered in the State Register of Immovable Monuments of Ukraine: 1167 landmarks of national importance and 14676 -of local significance (as of January 1, 2021) and 7 unique cultural objects included in the UNESCO World Heritage List, which have exceptional universal value.

Concerning religious and cultural heritage objects, as of January 1, 2021, 4173 religious buildings were granted the status of landmarks (excluding landmarks located on the territory of the occupied Crimean peninsula due to the impossibility of accounting and monitoring). ${ }^{9}$ All of them are subject to registration in the State Register of Immovable Monuments of Ukraine and acquire the status of a cultural monument regardless of the form of ownership.

The landmarks are systematized in the register by categories of national and local significance. According to the Procedure for determining the categories of landmarks, ${ }^{10}$ the objects proposed for inclusion in the register by category of national importance must retain their authenticity and have a significant impact on the development of cultural culture, be directly related to historical events, beliefs, life and activities of people who have made a significant contribution to the development of national culture, works of a vanished civilization or artistic style, or represent a masterpiece of creative genius. Objects proposed for inclusion in the register by category of local significance must retain their authenticity

\footnotetext{
${ }^{9}$ Report on the provision of churches and religious organizations of Ukraine with religious buildings and premises adapted for prayer as of January 1, 2021. State Service of Ukraine for Ethnopolitics and Freedom of Conscience, https://dess.gov.ua/ statistics-2020/ [accessed: 05.09.2021].

${ }^{10}$ Resolution of the Cabinet of Ministers of Ukraine No. 452 of May 22, 2019.
} 
and have an impact on the development of culture of a particular locality or region, be associated with historical events, beliefs, lives and activities of people who have made significant contributions in the development of the culture of a particular locality or region or to be the cultural heritage of a national minority or regional ethnic group.

To consider the case of entering the object of cultural heritage in the State Register of Immovable Monuments of Ukraine to the Ministry of Culture and Information Policy, a submission is submitted, as well as accounting documentation. Each landmark is assigned a unique security number [Myshchak 2015].

Within each of the categories (whether of national or local significance) landmarks are formed into species groups: archaeological, historical, monumental art objects, architectural objects, urban planning objects and others, as defined by Article 2 of the Law "On Protection of Cultural Heritage" and discussed above. Therefore, immovable objects of religious heritage: churches, monasteries, cathedrals, which have acquired the status of a "landmark," belong to the category of "Architectural landmark" in the State Register. However, in our opinion, this undermines the complex significance of a landmark, its historical weight, importance as a model of monumental art, and sometimes urban planning, science and technology.

\subsection{Objects of world importance}

A cultural heritage object of outstanding value and meeting the criteria set by the UNESCO World Heritage Committee may be nominated by the Ministry of Culture and Information Policy on the recommendation of the Ukrainian National Committee of the International Council on Monuments and Sites (IKOMOS) for the UNESCO World Heritage List. As of 2020, the World Heritage List included 1121 objects (869 cultural, 213 natural and 39 mixed) from 167 countries. This list currently includes seven Ukrainian cultural and natural landmarks, two of which have a religious purpose: St. Sophia Cathedral and adjacent monastery buildings, KyivPechersk Lavra (1990), as well as wooden churches in the Carpathian region of Ukraine and Poland (joint Ukrainian-Polish nomination, 2013).

The legal status of such landmarks is equated to landmarks of national importance with certain features. In particular: a) town-planning, architectural and landscape, earthworks on the World Heritage object, its terri- 
tory in the buffer zone are preceded by informing the UNESCO World Heritage Committee, the recommendations of which are mandatory for such works; b) for each world heritage object a heritage management body is formed or determined (following the procedure established by the Resolution of the Cabinet of Ministers of Ukraine No. 805 of July 24, 2019), which implements the measures provided for in the management plan, supervises any work on the world heritage object, monitoring the state of preservation of the World Heritage object and implementation of the decisions of the UNESCO World Heritage Committee, etc.; c) The Ministry of Culture and Information Policy shall establish a supervisory board to supervise the conservation status of the World Heritage Site and monitor the implementation of the World Heritage Management Plan (the procedure for formation and standard regulations were approved by the Cabinet of Ministers Resolution No. 805 of July 24, 2019).

\section{PROTECTION PROCEDURE}

Legislative regulation of organizational, social and economic relations in the field of protection of religious cultural heritage in order to preserve it, the use of objects in public life is carried out by the law "On Protection of Cultural Heritage," which is special to the law "On Basic Principles of State Supervision (Control) in the field of commercial activity," which also is highlighted by the case law (Supreme Court Judgment of 5 March 2020 in the case No. 826/6522/15 (administrative proceedings No. K/9901/ 14853/18). This gives us grounds to affirm that Ukraine has a model in which sacred places constitute, in essence, the subject of general law protection, as elements of cultural importance. The religious character may be acknowledged as an additional, yet unique, attribute of specific places or objects, that fall within the ambit of general legal provisions (lex generalis) [Tsivolas 2019, 283].

However, the legal regulation of the protection of cultural heritage in Ukraine, including religious cultural heritage, applies mainly to protective and restrictive measures [Rubanovs'kyy 2019, 24-25]. The maintenance and use of heritage are indirectly understood in the context of such con- 
cepts as adaptation, ${ }^{11}$ repair, ${ }^{12}$ rehabilitation, ${ }^{13}$ and are regulated by the law "On Protection of Cultural Heritage." However, these components, unfortunately, are not paramount.

\subsection{Property right}

The object of religious cultural heritage, whether it is classified as a landmark or not, can be in state, communal or private ownership (property of a religious organization). While the greatest part of the overall cultural (movable or immovable) property in Europe is owned by the respective States, religious cultural property in particular, is owned, in most cases, by other non-governmental organizations such as religious entities and private foundations or individuals [Tsivolas 2014, 87].

However, under Ukrainian law, landmarks can be alienated and privatized only with the consent of the cultural heritage protection authority and subject to the conclusion of a preliminary agreement with the relevant authority on the conclusion of a future protection agreement for the landmark. The security agreement is a relatively new type of agreement in the law enforcement practice of modern Ukraine, so it generates a number of controversial provisions [Piddubna 2013]. However, according to case law, it is a public-private law administrative agreement (Supreme Court Judgment of 23 December 2019 in case No. 806/1536/18; Supreme Court Judgment of 23 December 2019 in case No. 806/1536/18) and concluded between the owner of the landmark and the cultural heritage protection authority and establishes the regime of use of the landmarks of cultural heritage or its part, including the territory on which it is located. The content of protection agreements is to establish the peculiarities of the regime of use of a landmark, types and terms of restoration, conservation, repair works, works on landscaping, other landmark protection measures, the

${ }^{11}$ Modern use of a cultural heritage site without changing its inherent properties, which are the subject of protection of a cultural heritage object, including the restoration of elements that constitute historical and cultural value.

${ }^{12}$ Improving the technical condition and maintenance of the cultural heritage object without changing the properties that are the subject of protection of the cultural heritage object.

${ }^{13}$ Strengthening (conservation) of physical condition, disclosure of the most characteristic features, restoration of lost or damaged elements of cultural heritage objects with ensuring the preservation of their authenticity. 
need for which is determined by the relevant cultural heritage protection authority. The procedure for their conclusion and form shall be determined by the Procedure for concluding protection agreements for cultural heritage landmarks. ${ }^{14}$

The law also establishes a list of landmarks that are not subject to privatization. ${ }^{15}$ In this case, the landmarks are transferred for free use to religious organizations, if the issues related to the relocation of educational institutions, archives and cultural institutions that occupy these religious buildings to other premises are resolved. ${ }^{16}$ Exceptions are established for certain landmarks of state importance, which are not subject to transfer even for use: St. Sophia Cathedral as an object of the National Reserve "Sophia of Kyiv," rebuilt Assumption and St. Michael's Cathedrals in Kyiv and The Roman Catholic Church of St. Mary Magdalene in Lviv. However, a government act established the regime of their use for worship. ${ }^{17}$ In particular, St. Michael's Cathedral by the Patriarchate of the Ukrainian Orthodox Church - the Kyiv Patriarchate (now the Orthodox Church of Ukraine), the Assumption Cathedral of the National KyivPechersk Historical and Cultural Reserve - the Metropolitan of the Ukrainian Orthodox Church every day; The Roman Catholic Church of St. Mary Magdalene in Lviv - the Metropolitan of the Roman Catholic Church on Easter, the days of the twelfth and temple holidays, as well as major state events. By the way, St. Andrew's Church of the National Reserve "Sophia of Kyiv" until 2018 was also on the list of those who could not be transferred for permanent use. However, in order to create conditions for the Church of the Ecumenical Patriarchate to perform services in Ukraine, the church was transferred to the Ecumenical Patriarchate for free permanent use for worship, religious rites, ceremonies and processions. ${ }^{18}$

In total, out of 4173 religious buildings that have been granted the status of monuments, 2288 are owned by religious organizations, and 1885 have been handed over for use. In terms of confessions, it is as follows: the

\footnotetext{
${ }^{14}$ Resolution of the Cabinet of Ministers of Ukraine No. 1768 of December 28, 2001.

${ }^{15}$ About the List of cultural heritage monuments that are not subject to privatization: Law of Ukraine No. 574-VI of September 23, 2008.

${ }^{16}$ Resolution of the Cabinet of Ministers of Ukraine No. 137 of February 14, 2002.

${ }^{17}$ Resolution of the Cabinet of Ministers of Ukraine No. 1005 of July 9, 2001.

${ }^{18}$ On the peculiarities of the use of St. Andrew's Church of the National Reserve "Sophia of Kyiv": Law of Ukraine No. 2598-VIII of October 18, 2018.
} 
Orthodox Church of Ukraine owns 352 landmarks, 570 - transferred to it for use; The Ukrainian Orthodox Church (Moscow Patriarchate) owns 727 landmarks, and 1029 have been handed over to it; The Ukrainian Greek Catholic Church owns 1038 landmarks and 141 have been handed over for use; The Roman Catholic Church in Ukraine has 138 landmarks, 109 of which have been handed over for use; other confessions own and use several facilities.

The state, represented by the Ministry of Culture and Information Policy, has the right to privileged purchase of a landmark of national importance, and the cultural heritage protection authorities of regions, Kyiv and Sevastopol city, district public administrations and the relevant executive authorities of village, settlement, city council - of local significance. Therefore, the approval of the cultural heritage protection authority must contain information on the waiver of the right of preferential purchase granted to the cultural heritage protection authority. This position is also reflected in the case law on the relevant categories of cases: Decision of the Zhovkva District Court of Lviv region of March 16, 2016 in the case No. 444/2291/15ts; Decision of the Prymorskyi District Court of Odesa of May 23, 2017 in case No. 522/17340/13-ts.

Legal regulation and case law in disputes over the exercise of property rights of individuals is aimed at ensuring a fair balance of private and public interests, which consists in compliance by owners, business entities with the requirements of legislation on cultural heritage protection (Supreme Court Resolution of August 21, 2019 in case No. 826/12524/18).

The protection and preservation of landmarks are the responsibilities of the religious organizations in which they are owned or used. Among the responsibilities of owners and users are the following: to maintain the landmark in good condition, to protect it from damage, destruction or extermination, not to carry out activities that pose a threat to landmarks; use them according to the modes of use, without changing the purpose of the landmark, its parts and elements; to allow persons authorized by the authorities of cultural heritage protection to objects of cultural heritage for the purpose of their inspection, acquaintance with the state of storage, nature and method of use, scientific study, etc.; to notify the cultural heritage protection authority of the threat to the preservation of the landmark; timely carry out repair and restoration works of the landmark (its parts) and works on landscaping of the landmark; organize free access to 
landmarks for the purpose of their sightseeing, if they are considered suitable for this and other responsibilities; enter into a protection agreement with the body for the protection of cultural heritage.

\subsection{Conservation, restoration, repair and adaptation of landmarks}

The issue of effective management and sustainable use of religious heritage objects is currently extremely important. Conservation, restoration, repair and adaptation of monuments are carried out with the written permission (for landmarks of national importance issued by the Ministry of Culture and Information Policy, and for local significance - by regional public administrations) and on the basis of agreed research and design documentation. Permits and approvals are provided by the cultural heritage protection authorities free of charge in the order of providing administrative services, and the acquisition of the right on a declarative basis (the principle of tacit consent) is prohibited.

However, when it comes to objects of national or even global importance, such monuments are given much more attention and interest, scientific and practical activities ${ }^{19}$ are carried out and funding is directed. In particular, only this year (2021) in the framework of the project "Great Restoration" within the presidential program "Great Construction" work began on some individual objects that are cultural landmarks of religious significance, although there is no criteria for the selection of landmarks that should be applied to the funding of budget programs [Kryvets'ka $2019,49]$. In particular, we are talking about the restoration with the adaptation of the architectural landmark of national importance "Trinity Gate Church of the National Kyiv-Pechersk Historical and Cultural Reserve," repair and restoration work and adaptation of the architectural monument of the XVII-XVIII centuries. Onufriy Tower of the KyivPechersk Lavra in Kyiv, development of the project of repair and restoration works of the Bell Tower of St. Sophia Cathedral and current repair

\footnotetext{
${ }^{19}$ International Workshop for World Heritage Site "Living Religious Heritage of World Importance: Shared Governance and Sustainable Use". Managers, http://mincult. kmu.gov.ua/control/uk/publish/article?art_id=245429219\&cat_id=244913751 [accessed: 10.10.2021].
} 
of the stage of St. Sophia Cathedral of the National Reserve "Sophia of Kyiv." ${ }^{20}$

Sufficient attention has also recently been paid by the international community to cultural heritage objects left in the occupied Crimea. Thus, the official website of UNESCO published the report of the Director General of UNESCO at the 212th session of the Executive Council for monitoring the situation in the Autonomous Republic of Crimea, which will be considered under item 5.I.E of the agenda of the 212th session of the Executive Council ${ }^{21}$ in October 2021. The draft decision of this session includes provisions on the need to submit the next report on this issue in November 2022.

Instead, not all cultural heritage objects, even those of national or local importance, are in proper sustainable use. This is also evidenced by the materials of parliamentary hearings held in 2019 on "The State, Problems and Prospects for the Protection of Cultural Heritage in Ukraine."22 According to the results of the hearings, it was recommended to assist in the formation and development of public-private partnership in the field of cultural heritage protection by attracting non-governmental forms of investment to ensure the maintenance of monuments and the necessary work, providing tax benefits to preserve and develop cultural heritage. support for patronage in the field of cultural heritage protection.

However, we believe that the proper protection of religious heritage objects requires, above all, legal measures related to the improvement of procedures for the current monitoring of their protection, preservation and use.

Concerning landmarks, the Ministry of Culture and Information Policy of Ukraine currently exercises the authority to issue permits for works, supervise the restoration, repair, adaptation of monuments, approval of protection agreements, establish the mode of use and issue orders and in-

${ }^{20} \mathrm{On}$ approval of the list of projects to be implemented under the "Large Construction" program in 2021: Order of the Ministry of Culture and Information Policy No. 337 of May 18, 2021.

${ }^{21}$ Follow-up of the situation in the Autonomous Republic of Crimea (Ukraine). UNESCO. Executive Board, 212th, 2021. 212 EX/5.I.E, https://unesdoc.unesco.org /ark:/48223/pf0000378910?fbclid=IwAR3LX1lau-U81jszefMskmTWZeVZL-aX-QAWkD ZieOIY5RXxXrb8PB1FDfE [accessed: 05.09.2021].

${ }^{22}$ Recommendations of the parliamentary hearings on the topic: "Status, problems and prospects of protection of cultural heritage in Ukraine": Resolution of the Verkhovna Rada of Ukraine of May 14, 2019 No. 2716-VIII, http://www.golos.com.ua/article/ 317674 [accessed: 28.09.2021]. 
structions on protection of monuments of national importance. Similar powers related to landmarks of local significance are exercised by local executive bodies: region and district public administrations. Violation of the law is subject to criminal, administrative and financial liability. However, the rational management of a cultural heritage object involves not only and not so much bringing to justice violators of the requirements established by law, but ensuring the integrity, safety of the object and its intended use. Therefore, legal instruments should be aimed at the current control, supervision and monitoring of the cultural heritage site. In this context, it is necessary to approve the general method of determining the modes of use of the landmark depending on its type and purpose. This is especially important for religious sites. In addition, the state of protection, preservation and use of cultural heritage objects should also be monitored in accordance with a standardized methodology in order to narrow the discretion of the authorities and prevent arbitrary decisions.

For religious heritage objects that are not listed as landmarks, they are administered as part of the implementation of general cultural heritage protection programs. Of course, this is not enough. In addition, even liability for violations of cultural heritage legislation applies only to landmarks. Thus, persons are brought to administrative responsibility in case of violation of the legislation on protection of cultural heritage, namely, evasion of signing protection agreements on cultural heritage landmarks, violation of the regime of use of cultural heritage landmarks, repair, restoration, rehabilitation works, change appointment of a landmark of cultural heritage, implementation of inscriptions, marks on it, on its territory and in its protection zone without the permission of the body of protection of cultural heritage (Article 92 of the Code of Ukraine about Administrative Offenses). Administrative liability of legal entities that are owners or customers of works is to apply financial sanctions for any illegal work that may cause or have caused damage to the monument, its territory for failure to comply with the requirements for protection, preservation, use, restoration, intentional bringing them to a state of destruction, for evading the owner of the landmark or his authorized body from signing a protection agreement or for violating the regime of use of the monument, for non-compliance with the instructions of cultural heritage protection authorities (Article 44 of the Law "On Protection of Cultural Heritage"). Also, the distinction of illegal actions regarding religious buildings or sanctuaries 
from adjacent crimes in the criminal code is not always clear [Bilash 2013, 281]. And only the analysis of objective and subjective signs of crimes allows to distinguish clearly related crimes [Idem 2021, 17].

\section{CONCLUSIONS}

Proper preservation and protection of religious cultural heritage in Ukraine is exposed to several legal issues.

The first issue is the question of terminological certainty, the question of the unification of concepts. In particular, legislative acts use such concepts as cultural heritage object, cultural heritage landmark, historical and cultural landmark, cultural values, cultural goods, etc., the State Register of National Cultural Heritage and the State Register of Immovable Monuments of Ukraine are formed and completed. However, in our opinion, it is expedient to standardize the concept of "immovable objects of cultural heritage" to denote immovable objects of tangible cultural heritage that fall under the protection of the Law "On Protection of Cultural Heritage" and 'On Protection of Archaeological Heritage'.

The second issue is the revision of the classification of landmarks by species. Species systematization of immovable monuments by species, depending on the purpose and the information embodied in them, should have utilitarian and narrow practical significance. Belonging to one or another species should determine the mode of use, protective measures, monitoring procedure by the relevant authorities, etc. Accordingly, among the types of landmarks defined by law and provided for in the State Register of Immovable Monuments of Ukraine, such a type as religious landmarks (religious and church life) should be fixed.

The third problem is the lack of a generalized method of determining the modes of use and methods of monitoring the landmark, depending on its type and kind. The authority entrusted with the powers of monitoring and supervision shall determine the mode of use. However, to ensure the principles of legal certainty and legality, narrowing the discretion of the authorities, and as a result - improving the preservation and use of the object there should be approved a generalized method of determining the modes of use and monitoring of the landmark depending on its type and kind. 
In addition, particular changes should be made to legislation governing administrative liability for violations of cultural heritage. A significant point here is a question of expansion of the objective side of offenses and inclusion into a subject of offenses not only landmarks of cultural heritage, but also other objects which do not have such status.

\section{REFERENCES}

Bilash, Oleksandr. 2013. "Problemy vidmezhuvannya nezakonnykh diy shchodo relihiynykh sporud abo svyatyn' vid sumizhnykh skladiv zlochyniv." Chasopys Kyyivs'koho universytetu prava 3:279-83.

Bilash, Oleksandr. 2021. "Strafrechtliche Verantwortung bei Rechtsverstosen gegen den Schutz der Sakralbauten oder Heiligtumer gemas der Gesetzgebung der Ukraine.” Kościót i Prawo 10 (23), no. 1:9-22. https://doi.org/10.18290/kip21101-1

Bondarenko, Olena, Hanna Putova, and Pavlo Koval'ov. 2008. “Znyshchennya pam'yatok istoriyi ta kul'tury Kyyeva. Styslyy ohlyad za 2007 rik.” Forum spasennya Kyeva. http://forumspaskiev.org.ua/databox/2007/05/17147.php [accessed: 10.09.2021].

Boyko, Oksana. 2008. "Tserkvy horyat' v nezalezhniy Ukrayini, abo Bezkarnist' vandaliv." Elektronnyy resurs: Zakhidna analitychna hrupa. http://arhiv.orthodoxy. org.ua/uk/2008/03/19/14965.html [accessed: 03.10.2021]

Connolly, Anthony J., ed. 2015. Cultural Heritage Rights. London: Routledge.

Fedorova, Larysa D. 2015. "Pam'yatky istoriyi u zahal'niy systemi kul'turnoyi spadshchyny." In Kul'turna spadshchyna v konteksti «Zvodu pam'yatok istoriyi ta kul'tury Ukrayiny», ed. Serhiy I. Kot, Halyna H. Denysenko, Hlib YU. Ivakin, et al. 486. Kyyiv: Instytut istoriyi Ukrayiny.

Kot, Serhiy I. 2009. "Pam'yatka." http://www.history.org.ua/?termin=Pamiatka [accessed: 07.10.2021].

Kot, Serhiy I. 2015. "Istorychnyy dosvid ta aktual'ni problemy zberezhennya pam'yatok istoriyi ta kul'tury Ukrayiny." In Kul'turna spadshchyna v konteksti «Zvodu pam'yatok istoriyi ta kul'tury Ukrayiny», ed. Serhiy I. Kot, Halyna H. Denysenko, Hlib YU. Ivakin, et al. 486. Kyyiv: Instytut istoriyi Ukrayiny.

Kot, Serhiy I. 2018. "Pro stan zberezhennya kul'turnoyi spadshchyny Ukrayiny." In Informatsiyno-analitychni materialy do parlament.s'kykh slukhan' "Stan, problemy ta perspektyvy okhorony kul'turnoyi spadshchyny v Ukrayini» 18 kvitnya 2018 r. 43. Kyyiv: Instytut istoriyi Ukrayiny NAN Ukrayiny.

Kovpanenko, Natalaya H. 1999. "Pam'yatky monumental'noho zhyvopysu." In Aktual'ni problemy vyyavlennya i doslidzhennya pam'yatok istoriyi ta kul'tury. Part 2, 212-45. Kyyiv: Instytut istoriyi Ukrayiny NAN Ukrayiny.

Kryvets'ka, Liliya. 2019. Upravlinnya mistsevoyu kul'turnoyu spadshchynoyu $v$ Ukrayini: ohlyad derzhavnoyi polityky, dzherel ta modeley finansuvannya: Bila knyha. L'viv: Laboratoriya mis'koho prostoru. 
Mazur, Tamara V. 2021. Okhorona kul'turnoyi spadshchyny v Ukrayini: istoryko- y teoretyko-pravove doslidzhennya. Dysertatsiya na zdobuttya stupenya doktora yurydychnykh nauk. Kyyiv.

Myshchak, Ivan M. 2015. "Pravove rehulyuvannya protsesu formuvannya y napovnennya Derzhavnoho reyestru nerukhomykh pam'yatok Ukrayiny.” Naukovi zapysky Instytutu zakonodavstva Verkhovnoyi Rady Ukrayiny 2:15-20.

Piddubna, Victoriya F. 2013. "Shchodo pidstav nabuttya mayna relihiynymy orhanizatsiyamy." Teoriya $i$ praktyka pravoznavstva 2. http://nbuv.gov.ua/UJRN/tipp _2013_2_10 [accessed: 28.09.2021].

Rubanovs'kyy, Kyrylo, ed. 2019. Analiz problem u zakonodavchomu rehulyuvanni zberezhennya ta upravlinnya kul'turnoyu ta pryrodnoyu spadshchynoyu $v$ Ukrayini. Ivano-Frankivs'k: Ahentstvo z rozvytku pryvatnoyi initsiatyvy.

Slipchenko, Nataliya. 2001. "Inventarizatsiya mystets'kykh tvoriv u pam'yatkakh arkhitektury." Pam'yatky Ukrayiny: istoriya ta kul'tura 4:130-33.

Tokman, Volodymyr V. 2014. "Problemy zberezhennya ta zakhystu kul'turno-relihiynykh tsinnostey Ukrayiny." Analitychna zapyska. Natsional'nyy instytut stratehichnykh doslidzhen'. http://old.niss.gov.ua/articles/1434/ [accessed: 25.09.2021].

Tsivolas, Theodosios. 2014. Law and Religious Cultural Heritage in Europe. Germany: Springer International Publishing.

Tsivolas, Theodosios. 2019. "The Legal Foundations of Religious Cultural Heritage Protection.” Religions 10 (4):283. https://doi.org/10.3390/rel10040283

Yepifanov, Oleksandr V. 2017. "Problemy udoskonalennya normatyvno-pravovoho rehulyuvannya okhorony kul'turnoyi spadshchyny u konteksti konstytutsiynoyi modernizatsiyi." Naukovi zapysky Instytutu zakonodavstva Verkhovnoyi Rady Ukrayiny 2:34-39.

Yepifanov, Oleksandr V. 2018. Konstytutsiyno-pravovi zasady okhorony kul'turnoyi spadshchyny: problemy teoriyi ta praktyky. Dysertatsiya na zdobuttya stupenya kandydata yurydychnykh nauk. Kharkiv.

\title{
Preservation and Protection of the Cultural Heritage of Religious Purposes in Ukraine
}

\begin{abstract}
The article deals with the current issues of preservation and protection of the cultural heritage of religious purpose in Ukraine at the modern stage and attempts to formulate legal problems and propose their solutions. The authors conclude that the proper preservation and protection of cultural heritage is fraught with the following legal obstacles. The first is the question of terminological certainty, the question of the unification of concepts. The second problem is the revision of the classification of landmarks into species and the separation of such species as religious landmarks (religious and church-life). The third problem is the lack of a generalized methodology for determining the modes of use and monitoring of the landmark depending on its
\end{abstract}


type and kind, as well as the imperfection of legislation governing administrative liability for violations of cultural heritage.

Keywords: cultural heritage; religious cultural heritage; landmark; religious buildings; immovable cultural heritage

\title{
Zachowanie i ochrona dziedzictwa kulturowego o celach religijnych na Ukrainie
}

\begin{abstract}
Abstrakt
Artykuł jest poświęcony współczesnym i aktualnym problemom zachowania oraz ochrony dziedzictwa kulturowego na Ukrainie. Autorzy próbują też sformułować problemy prawne tego zjawiska i zaproponować ich rozwiązanie. Autorzy doszli do wniosku, że dostateczne zachowanie i ochrona dziedzictwa kulturowego są obarczone następującymi problemami prawnymi. Pierwszy to kwestia pewności terminologicznej, kwestia unifikacji pojęć. Drugi problem - to kwestia zrewidowania klasyfikacji zabytków i wyodrębnienie takiego rodzaju zabytku, jak zabytki religijne (związane z życiem religijnym i kościelnym). Trzecim problemem jest brak ogólnych metod określania sposobów użytkowania oraz metod monitorowania zabytków w zależności od ich rodzaju i typu, oraz niedoskonałość aktów prawnych, które regulują odpowiedzialność administracyjną za naruszenie przepisów ochraniających dziedzictwo kulturowe.
\end{abstract}

Słowa kluczowe: dziedzictwo kulturowe, dziedzictwo religijne, zabytek, budowle kultu, nieruchome dobra kultury

Informacje o Autorze: DR OlEKSANDR BILASH - Katedra Prawa Administracyjnego, Finansowego i Informatycznego, Użhorodzki Uniwersytet Narodowy; adres do korespondencji: Kapitulna street 26, 88000 Uzhhorod, Ukraina; e-mail: oleksandr. bilash@uzhnu.edu.ua; https://orcid.org/0000-0002-1248-7798

Informacje o Autorze: Prof. DR HAB. TETYANA KARABIN - Katedra Prawa Administracyjnego, Finansowego i Informatycznego, Użhorodzki Uniwersytet Narodowy; adres do korespondencji: Kapitulna street 26, 88000 Uzhhorod, Ukraina; e-mail: tetyana.karabin@uzhnu.edu.ua; https://orcid.org/0000-0002-6538-5269

Informacje o Autorze: Prof. DR haB. MYKhaIlo SAVChyN - Katedra Prawa Administracyjnego, Finansowego i Informatycznego, Użhorodzki Uniwersytet Narodowy; adres do korespondencji: Kapitulna street 26, 88000 Uzhhorod, Ukraina; e-mail: michaelsavchyn7@gmail.com; https://orcid.org/0000-0002-9551-1203 